\title{
Pichia inositovora and Candida paludigena, Two New Species of Yeasts Isolated from Peat
}

\author{
W. I. GOLUBEV, VALENTINA M. BLAGODATSKAYA, S. O. SUETIN, AND RAYA SH. TROTSENKO \\ Institute of Biochemistry and Physiology of Microorganisms, U.S.S.R. Academy of Sciences, Pushchino, \\ Moscow region 142292, U.S.S.R.
}

\begin{abstract}
Representatives of two new yeast species, Pichia inositovora and Candida paludigena, have been recovered from highmoor peat. $P$. inositovora forms two to four hat-shaped spores in the ascus; each of the ledges of the ascospores has a bulb at the end. It is nonfermentative and inositol positive C.paludigena forms abundant true mycelium with conidia on denticles. The cell wall structure corresponds to that of ascomycetous yeasts. This species is urease negative, inositol positive, nonfermentative, and nitrate negative. The type strains of these species are AM-125 (=CBS 0000; =IBPhM Y-888) and AM-146 (=CBS 0000; $=\mathrm{IBPhM}$ Y-917), respectively.
\end{abstract}

During a survey of the yeast flora associated with peats of different bogs (W. I. Golubev, V. M. Blagodatskaya, A. R. Manukian, and O. L. Liss, Izv. Akad. Nauk SSSR Ser. Biol., in press), several organisms were recovered which could not be identified with any of the species known at present. Some of these isolates exhibited such significant differences in taxonomic characteristics from the closest species that establishment of novel species was justified.

The present paper reports the results of the taxonomic examination and characterization of two new inositol-positive species, Pichia inositovora and Candida paludigena.

\section{MATERIALS AND METHODS}

All isolates were obtained from highmoor peat collected in the Moscow region (Golubev et al., in press). The isolations were done by plating peat suspensions in sterile water on acidified malt agar (malt extract agar $+4 \mathrm{ml}$ of $40 \%$ lactic acid per liter). The yeast described under the name $P$. inositovora was isolated only once, whereas $C$. paludigena was consistently found in large numbers. The description of the latter species is based on a study of 15 strains.

Identification was done by standard methods currently used in yeast taxonomy (12). For transmission electron microscopy, the cultures were grown on malt agar at $20^{\circ} \mathrm{C}$. The harvested cells were washed with water and fixed with $1 \%$ glutaraldehyde in $0.1 \mathrm{M}$ phosphate buffer (pH 7.2) and then postfixed with $1 \%$ $\mathrm{OsO}_{4}$ in the same buffer. Sections of this material embedded in Araldite were stained with $3 \%$ uranyl acetate.

\section{RESULTS}

Latin diagnosis of the new species: Pichia inositovora Golubev et Blagodatskaya sp. nov.

In medio liquido cellulae spheroidales vel ovoideae, $1.6-6.0 \times 3.7-9.0 \mu \mathrm{m}$, singulae, binae; se- dimentum et interdum pellicula tenuis formantur.

Cultura in medio eodem agaro post unum mensem $\left(20^{\circ} \mathrm{C}\right)$ alba vel cremea, glabra, nitida vel semi-nitida, mollis; margine glabro.

Pseudomycelium primitivum formatur.

Asci inconjugati fiunt. Ascosporae 2-4 in asco, pileiformae. Ascosporae maturae ex ascis liberantur.

Fermentatio glucosi nullum. Glucosum, galactosum, L-sorbosum, saccharum, maltosum, cellobiosum (lente), trehalosum, melezitosum, xylosum, ethanolum (exigue), glycerolum, ribitolum, mannitolum, glucitolum, $\alpha$-methyl-D-glucosidum, salicinum (lente), acidum lacticum (lente), acidum succinicum, acidum citricum, glucono- $\delta$-lactonum, acidum glucuronicum, et $i$-inositolum assimilantur at non lactosum, melibiosum, raffinosum, inulinum, amylum, L- et D-arabinosum, ribosum, L-rhamnosum, methanolum, erythritolum, galactitolum, nec 5-ketogluconatum.

Arbutinum finditur.

Kalium nitricum non assimilatur.

Ad crescentiam biotinum et thiaminum necessariae sunt.

In medio $50 \%$ glucosum continente non crescit.

In $30^{\circ}$ non crescit.

Urea non finditur.

Typus: Stirps AM-125 ex turfa isolata est. In collectione Instituti Biochemiae et Physiologiae Microorganismorum, Acad. Sci. U.R.S.S. (Pushczino), sub no. 888 deposita est.

Description of $P$. inositovora. Growth in liquid media (yeast morphology medium, glucoseyeast extract-peptone water, or malt extract): in all media used and after 3 days, the cells are 
spheroidal or ovoidal, measure 1.6 to 6.0 by 3.7 to $9.0 \mu \mathrm{m}$, and occur singly and in pairs. A very thin, dull, smooth, creeping pellicle may be formed in yeast morphology medium.

Growth on solid media (yeast morphology agar [Difco], glucose-yeast extract-peptone agar, or malt agar): on all media used, and after 1 month, the streak culture is white or slightly cream-colored, smooth, glossy to semiglossy, and soft; the border is entire.

Dalmau plate culture on yeast morphology or cornmeal agar: after 12 days, a rudimentary pseudomycelium is present.

Formation of ascospores: vegetative cells are transformed into asci which contain two to four hat-shaped ascospores, surrounded at the base by a brim (Fig. 1). The ledge has a bulb at the end (Fig. 2). The asci lyse upon maturity, releasing the spores. Sporulation occurs abundantly on malt agar, giving the growth a cream color.

Fermentation: glucose is not fermented.

Assimilation of carbon compounds: D-glucose, D-galactose, L-sorbose, maltose, sucrose, cellobiose (slow), trehalose, melezitose, D-xylose, ethanol (weak), glycerol, ribitol, D-mannitol, Dglucitol, $\alpha$-methyl-D-glucoside, salicin (slow), lactic acid (slow), succinic acid, citric acid, glucono- $\delta$-lactone, D-glucuronic acid, and $i$-inositol are assimilated.
Lactose, melibiose, raffinose, inulin, soluble starch, L-arabinose, D-arabinose, D-ribose, Lrhamnose, methanol, erythritol, galactitol, and 5-ketogluconate are not assimilated.

Splitting of arbutin: positive.

Assimilation of potassium nitrate: negative.

Vitamins required: biotin and thiamine.

Growth on $50 \%$ (wt/wt) glucose-yeast extract agar: absent.

Growth at $30^{\circ} \mathrm{C}$ : absent.

Hydrolysis of urea: negative.

Gelatin liquefaction: negative.

Type strain: the type strain, AM-125, was isolated from highmoor peat in the Moscow region, U.S.S.R., in 1977. It has been deposited in the collection of microorganisms, Institute of Biochemistry and Physiology of Microorganisms, U.S.S.R. Academy of Sciences, Pushchino, as IBPhM Y-888, and in the Centraalbureau voor Schimmel-cultures (CBS), Baarn, Netherlands, as CBS 0000.

Etymology: inositovora. L.n. inositolum inositol; L.v. voro devour; L. fem. adj. inositovora inositol-assimilating.

Latin diagnosis of Candida paludigena Golubev et Blagodatskaya sp. nov.

In medio liquido cellulae spheroidales vel ovoideae, 1.7-4.8 $\times 1.7-7.7 \mu \mathrm{m}$, singulae, binae, in

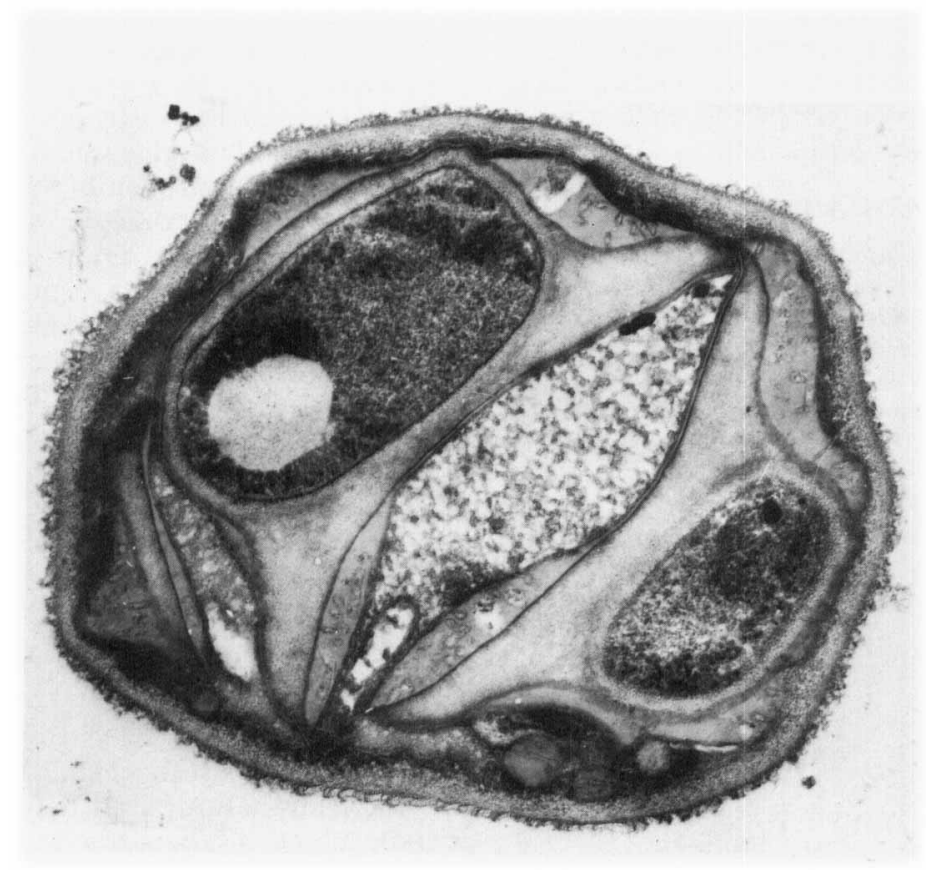

FIg. 1. Ascus of P. inositovora strain AM-125 with two hat-shaped spores. Malt agar, $20^{\circ} \mathrm{C}, 2$ weeks; magnification, $\times 30,000$. 


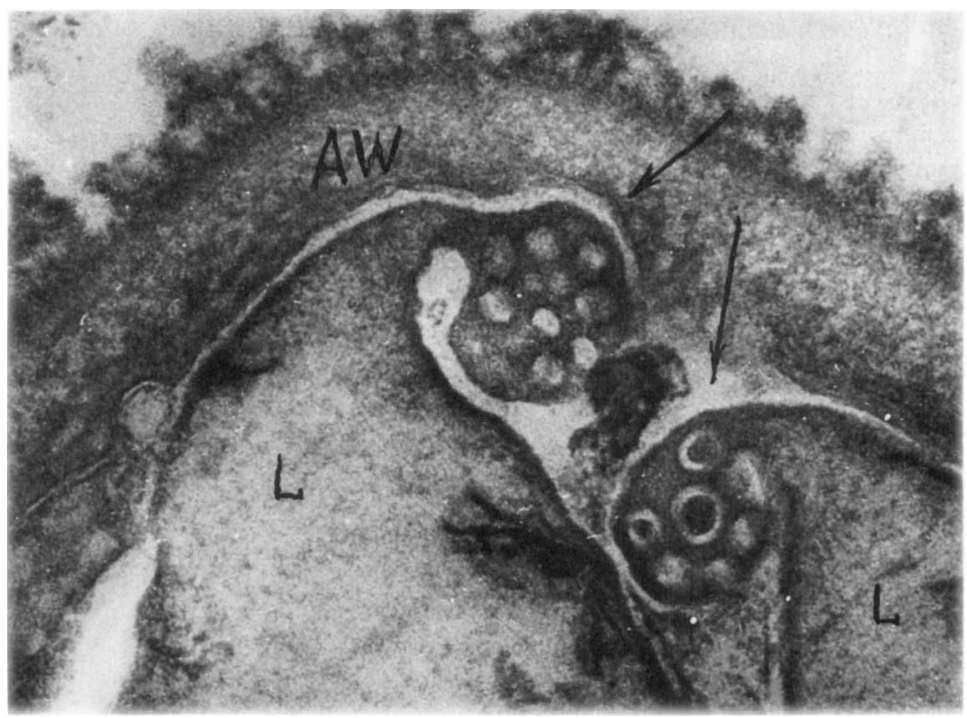

FIg. 2. Part of a section through the spores in an ascus of $P$. inositovora AM-125. The arrows indicate the bulbs at the ends of the ledges (L). AW, Wall of the ascus. Malt agar, $20^{\circ} \mathrm{C}, 2$ weeks; magnification, $\times 100,000$.

catenis. Capsula non formatur. Hyphae et pseudohyphae praesentes. Post unum mensem pellicula et sedimentum formantur.

Cultura in medio eodem agaro post unum mensem $\left(20^{\circ} \mathrm{C}\right)$ albidaeburna, non nitida, tenaces rugosa; margine fimbriatus.

In agaro farinae Zea mais post dies 10 hyphae septate dominantes, ramosae, hyalinae. Cellulae conidiogenae intercalaris vel terminales, denticulatae. Conidia parva, hyalina, lateralis vel terminales, denticulis oriunda. Arthroconidia absentes.

Ascosporae vel teliosporae non formantur.

Ultrastructura parietis sicut in fermentis ascomycetoideis.

Fermentatio glucosi nullum. Glucosum, galactosum, L-sorbosum (lente), saccharum, maltosum (data occasione lente), trehalosum, cellobiosum, melezitosum, D-xylosum, L-arabinosum (lente), L-rhamnosum (exigue), ethanolum, glycerolum, $\alpha$-methyl-D-glucosidum (lente), salicinum, acidum lacticum, acidum succinicum, acidum citricum, $i$-inositolum, acidum glucuronicum, glucono- $\delta$-lactonum, et 5-ketogluconatum assimilantur at non melibiosum, raffinosum, amylum, inulinum, D-arabinosum, D-ribosum, erythritolum, ribitolum, galactitolum, nec glucitolum. Assimilatio lactosi et mannitoli variabilis.

Arbutinum finditur.

Kalium nitricum non assimilatur.

Ad crescentiam thiaminum necessariae est.

In $37^{\circ} \mathrm{C}$ non crescit.

Acidum non format.

Urea non finditur.

Gelatinum non liquefit.
Sedum bovillum non finditur.

Materia amyloidea iodophila non formatur.

Typus: Stirps AM-146 ex turfa isolata est. In collectione Instituti Biochemiae et Physiologiae Microorganismorum, Acad. Sci. U.R.S.S. (Pushczino) sub no. 917 deposita est.

Description of $C$. paludigena. Growth in liquid media (yeast morphology medium, glucoseyeast extract-peptone water, or malt extract): in all media used and after 3 days, the cells were spheroidal or ovoidal and measured 1.7 to 4.8 by 1.7 to $7.7 \mu \mathrm{m}$; they occurred singly, in pairs, and in chains. No capsule was demonstrable. Septate hyphae measure 1.7 to $2.7 \mu \mathrm{m}$ in diameter. A pellicle and a sediment are formed.

Growth on solid media (yeast morphology agar [Difco], glucose-yeast extract-peptone agar, or malt agar): on all media used, and after 1 month, the streak culture is light cream colored, tough, dull, and rugose, with fimbriate margin.

Dalmau plate culture on yeast morphology or cornmeal agar: septate hyphae predominate. Conidiogenous cells are intercalary or terminal, denticulate (Fig. 3). Conidia are one-celled and spherical. The mycelium does not fall apart into arthrospores. Sometimes the hyphae are swollen at the apices.

Ascospore, ballistospore, or teliospore formation: not observed in single and mixed cultures.

Fermentation: glucose is not fermented.

Assimilation of carbon compounds: D-glucose, D-galactose, L-sorbose (slow), sucrose, maltose (some strains slowly), trehalose, cellobiose, melezitose, D-xylose, L-arabinose (slow), L-rhamnose (weak), ethanol, glycerol, $\alpha$-methyl-D-glu- 
coside (slow), salicin, lactic acid, succinic acid, citric acid, D-glucuronic acid, glucono- $\delta$-lactone, 5 -ketogluconate, and $i$-inositol are assimilated.

Melibiose, raffinose, soluble starch, inulin, Darabinose, D-ribose, erythritol, ribitol, galactitol, and D-glucitol are not assimilated. Assimilation of lactose and D-mannitol is negative or weak and latent.

Splitting of arbutin: positive.

Assimilation of potassium nitrate: negative.

Vitamin required: thiamine.
Maximum temperature for growth: 32 to $35^{\circ} \mathrm{C}$. Acid formation on chalk agar: negative.

Hydrolysis of urea: negative.

Gelatin liquefaction: negative.

Lipolytic activity: negative.

Synthesis of starchlike compounds: negative.

Growth on $50 \%$ (wt/wt) glucose-yeast extract agar: absent. Slow growth on $30 \%$ glucose.

Maximum $\mathrm{NaCl}$ and $\mathrm{KCl}$ concentration for growth: 1 and 5\%, respectively.

Cell wall structure by transmission electron

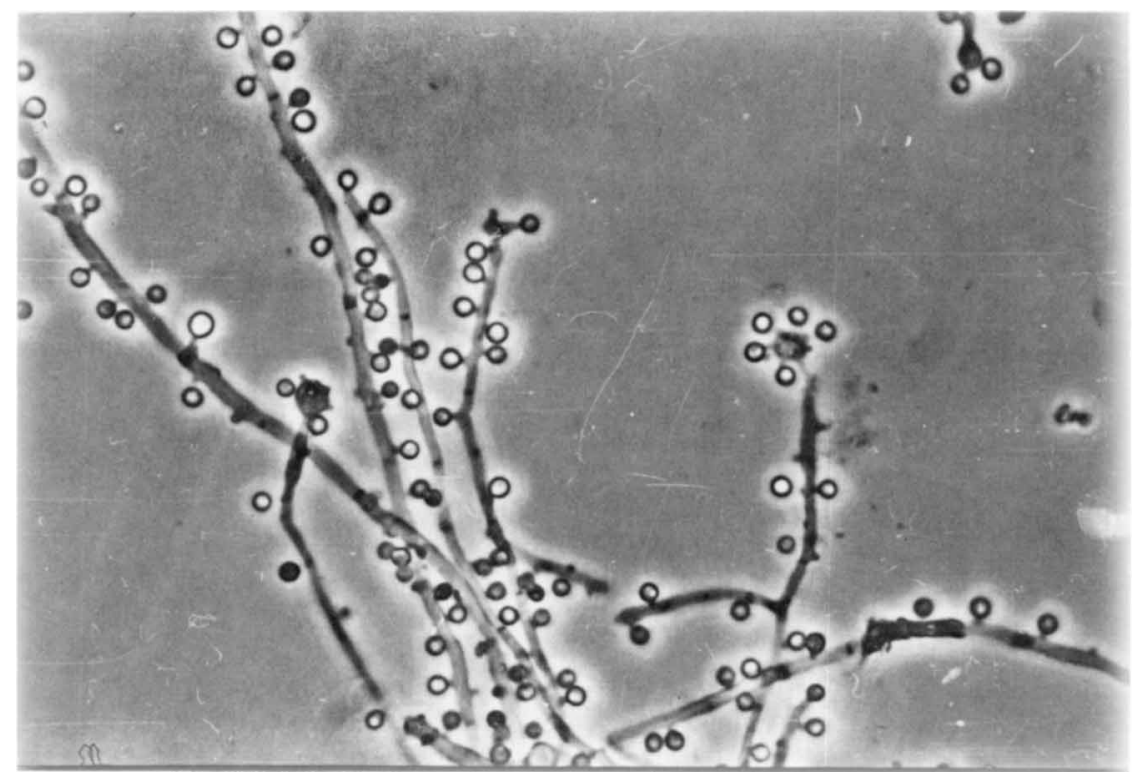

Fig. 3. C. paludigena AM-146 on yeast morphology agar. Hyphae with denticles and conidia. Growth: $20^{\circ} \mathrm{C}, 2$ weeks; magnification, $\times 1,000$.

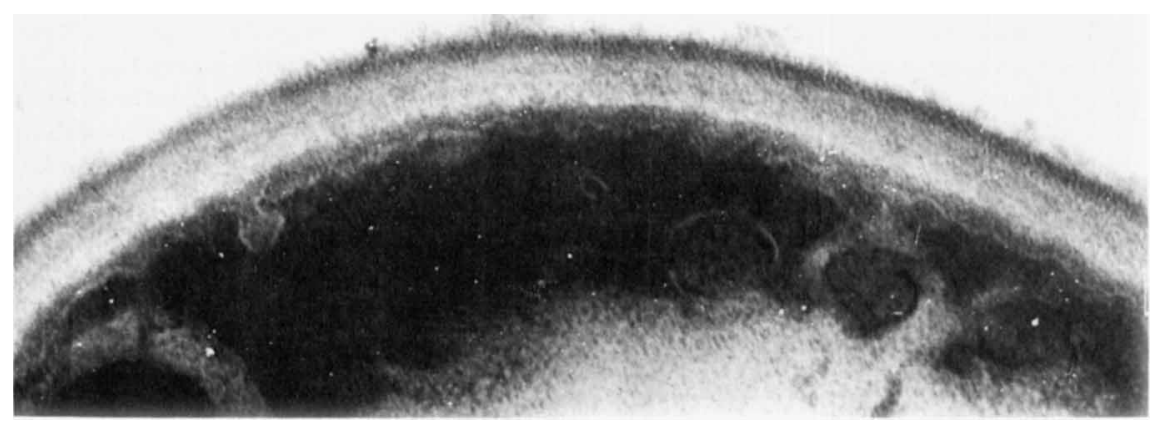

FIG. 4. Fragment of the cell wall of C. paludigena AM-146 with a dark outer layer and a broad, light inner layer. Malt agar, 2 days, $20^{\circ} \mathrm{C}$; magnification, $\times 75,000$. 
microscopy: sections showed the cell wall to be of the ascomycetous type and to consist of a dark outer and a lighter inner layer (Fig. 4).

Type strain: the type strain, AM-146, was isolated from highmoor peat in the Moscow region, U.S.S.R., in 1977. It has been deposited in the collection of microorganisms, Institute of Biochemistry and Physiology of Microorganisms, U.S.S.R. Academy of Sciences, Pushchino, as IBPhM Y-917, and in the Centraalbureau voor Schimmelcultures under the number CBS 0000 .

Etymology: paludigena. L.n. palus bog; L.v. geno generate; L. f. adj. paludigena, boggy, growing in a bog.

\section{DISCUSSION}

The ability to assimilate $i$-inositol is considered to be an important taxonomic characteristic which is used for delimiting yeast genera (4). In addition, this property, as a rule associated with the ability to assimilate D-glucuronic acid (1), is also used for delineating several species in the genus Candida. It is relatively rare among the yeasts, especially the ascomycetous ones.

On the basis of its morphological and physiological properties, $P$. inositovora fits very well in the genus Pichia Hansen as currently delineated (2). However, the definition of this genus is rather broad and allows the inclusion of species of divergent relationships. In recent years its heterogeneity has been shown convincingly $(5,7,13)$. In spite of the large number of pichias, the list of which keeps growing $(6,9,10), P$. inositovora is the first inositol-positive species. It resembles $P$. wickerhamii (van der Walt) Kreger-van Rij in morphological and physiological properties. However, besides the assimilation of inositol, $P$. inositovora differs from $P$. wickerhamii by utilizing galactose and sorbose but not rhamnose. Also, these species can be distinguished on the basis of glucose fermentation and the ability to grow at $37^{\circ} \mathrm{C}$. The new species is assumed to be homothallic, because heat treatment of ascosporic material according to the procedure devised for the recovery of mating types yielded self-sporulating cultures. An interesting feature of $P$. inositovora, not mentioned for any other yeasts with hat-shaped ascospores, is the presence of a bulb at the end of the ledge (Fig. 2). This bulb is not observed on all sections of ascospores. Obviously it is not present along the entire perimeter of the brim, and its revelation depends on the direction of the section. Morphology of ascospores has a high value in yeast taxonomy, but it is difficult to evaluate the significance of the bulb in $P$. inositovora ascospores because information on the ultrastructure of hat-shaped ascospores is insufficient.

Mycelial yeasts forming conidia on denticles are not numerous: they are the ascosporogenous, heterothallic organisms Hyphopichia burtonii (Boidin et al.) von Arx et van der Walt (11), Stephanoascus ciferrii Smith et al. (8), and Cephaloascus albidus Kurtzman (3); these may be recovered in their imperfect forms, e.g., Candida chodatii (Nechitch) Berkhout and Can-

TABLE 1. Physiological differences between Candida paludigena, Stephanoascus ciferrii, Hyphopichia burtonii, and Cephaloascus albidus

\begin{tabular}{|c|c|c|c|c|}
\hline Characteristic & C. paludigena & S. ciferrii & H. burtonii & C. albidus \\
\hline Fermentation of glucose & - & -/weak & $+/$ slow & weak, slow \\
\hline \multicolumn{5}{|l|}{ Assimilation of: } \\
\hline Sucrose & + & + & + & - \\
\hline Maltose & $+/$ slow & + & + & - \\
\hline Melibiose & - & + & - & + \\
\hline Raffinose & - & + & + & + \\
\hline Melezitose & + & - & $+1-$ & - \\
\hline Soluble starch & - & $+/-$ & + & - \\
\hline D-Arabinose & - & + & - & - \\
\hline D-Ribose & - & + & + & - \\
\hline L-Rhamnose & weak & + & - & - \\
\hline$i$-Erythritol & - & + & + & - \\
\hline Ribitol & - & + & + & + \\
\hline Galactitol & - & + & - & - \\
\hline Mannitol & $-/$ weak & $+/$ weak & + & + \\
\hline Glucitol & - & + & + & + \\
\hline$\alpha$-Methyl-D-glucoside & slow & $-/$ slow & + & - \\
\hline Lactic acid & + & + & - & weak \\
\hline$i$-Inositol & + & + & - & - \\
\hline Growth in vitamin-free medium & - & + & -/weak & - \\
\hline Growth at $37^{\circ} \mathrm{C}$ & - & + & $-/$ weak & - \\
\hline Sodium chloride tolerance (\%) & $1 \%$ & $11-16 \%$ & & $>10 \%$ \\
\hline
\end{tabular}


dida ciferrii Kreger-van Rij. The cell wall ultrastructure of $C$. paludigena (Fig. 4) indicates that this organism has ascomycetous affinity. The failure to demonstrate an ascigerous state suggests that all of the isolated strains represent one haploid mating type or, more probably, that they require particular conditions for sporulation. Our isolates cannot be identified with the imperfect states of the three sporogenous species mentioned since they differ from them in many respects. Unlike $S$. ciferrii (C. ciferrii) and $\mathrm{Ce}$ phaloascus albidus, the denticles of the new species are not clustered. Also, C. paludigena has single conidia and a mycelium from which arthrospores are not formed (Fig. 3), in contrast with $H$. burtonii (C. chodatii). In addition, there are rather numerous physiological differences (Table 1).

C. paludigena is absent in the peats of lowmoor and transitional bogs, but it is the common yeast found in highmoor peat, which has a low ash content and a low pH (Golubev et al., in press). This information, coupled with some of the physiological properties (optimum $\mathrm{pH}$ for growth near 4 and sensitivity to elevated concentrations of salt) of the isolates, suggests that highmoor peat is the natural habitat of this species.

\section{REPRINT REQUESTS}

Address reprint requests to: Dr. W. I. Golubev, Institute of Biochemistry and Physiology of Microorganisms, U.S.S.R. Academy of Sciences, Pushchino, Moscow region 142292, U.S.S.R.

\section{LITERATURE CITED}

1. Golubev, W. I., and V. M. Blagodatskaya. 1978. The significance of the ability to assimilate D-glucuronic acid, D-glucono- $\delta$-lactone and 5-keto-D-gluconate in identification of species of Candida Berkhout. Mikrobiologia 47:841-848.

2. Kreger-van Rij, N. J. W. 1970. Pichia Hansen, p. 455554. In J. Lodder (ed.), The yeasts, a taxonomic study. North-Holland Publishing Co., Amsterdam.

3. Kurtzman, C. P. 1977. Cephaloascus albidus, a new heterothallic yeast-like fungus. Mycologia 69:547-555.

4. Lodder, J. (ed.). 1970. The yeasts, a taxonomic study. North-Holland Publishing Co., Amsterdam.

5. Nakase, T., and K. Komagata. 1970. Significance of DNA base composition in the classification of yeast genus Pichia. J. Gen. Appl. Microbiol. 16:511-521.

6. Phaff, H. J., W. T. Starmer, M. Miranda, and M. W. Miller. 1978. Pichia heedii, a new species of yeast indigenous to necrotic cacti in the North American Sonoran desert. Int. J. Syst. Bacteriol. 28:326-331.

7. Poncet, S. 1975. Analyse numerique des 50 espèces classées dans le genre Pichia (Ascomycetes), Seconde application d'une méthode d'analyse factorielle. Mycopathologia 57:99-108.

8. Smith, M. T., J. P. van der Walt, and F. Johannsen. 1976. The genus Stephanoascus gen. nov. (Ascoideaceae). Antonie van Leeuwenhoek J. Microbiol. Serol. 42:119-127.

9. Starmer, W. T., H. J. Phaff, M. Miranda, M. W. Miller, and J. S. F. Barker. 1979. Pichia opuntiae, a new heterothallic species of yeast found in decaying cladodes of Opuntia inermis and in necrotic tissue of cereoid cacti. Int. J. Syst. Bacteriol. 29:159-167.

10. von Arx, J. A., L. Rodrigues de Miranda, M. T. Smith, and D. Yarrow. 1977. The genera of the yeasts and yeast-like fungi. Studies Mycol. N 14:1-42.

11. von Arx, J. A., and J. P. van der Walt. 1976. The ascigerous state of Candida chodatii. Antonie van Leeuwenhoek J. Microbiol. Serol. 42:309-314.

12. van der Walt, J. P. 1970. Criteria and methods in yeast classification, p. 34-113. In J. Lodder (ed.), The yeasts, a taxonomic study. North-Holland Publishing Co., Amsterdam.

13. Yamada, Y., T. Okada, O. Ueshima, and K. Kondo. 1973. Coenzyme $Q$ in the classification of the ascosporogenous yeast genera Hansenula and Pichia. J. Gen. Appl. Microbiol. 19:189-208. 